\title{
PREDIKSI HASIL PANEN PADI KABUPATEN \& KOTA DI PROPINSI NUSA TENGGARA TIMUR DENGAN FUZZY INFERENCE SYSTEM (FIS)
}

\author{
Yampi R. Kaesmetan \\ Program Studi Teknik Informatika, STIKOM Uyelindo Kupang \\ Jln. Perintis Kemerdekaan I - Kayu Putih - Kupang - NTT - Indonesia \\ Email : kaesmetanyampi@gmail.com
}

\begin{abstract}
Rice (Oryza sativa) is a staple food source for the people of Indonesia. Most of the rice consumed is the result of national rice productivity. Often the government has difficulty in estimating the adequacy of basic food items that can be provided by domestic agriculture. Therefore a method is needed to predict rice yields accurately and precisely. The agricultural sector in East Nusa Tenggara is not a flagship of the community's economic activities. This is due to the geographical conditions of NTT which are less supportive for business activities in the agricultural sector. Even so, the prediction of agricultural products, especially rice yields, is needed to be predicted so that a forecast can be obtained in determining rice yields in 2017. Fuzzy logic method in this case Fuzzy Inference System (FIS) is widely applied for forecasting or prediction. Fuzzy logic has a slowness in predicting crop yields for the following year based on crop yields in the previous year and information taken from the fuzzy information provided. Fuzzyinformation can be made a rule or rule as a consideration in predicting yields. By using the formula of Mean Absolute Percentage Error (MAPE) or Average Absolute Error, from the Fuzzy Mamdani model The Fuzzy Inference System (FIS) with the Mamdani model that has been built can be used to estimate the amount of rice production in the City District in NTT with the truth value reaching 97.8\%. To determine the amount of rice production in 2017, the data is processed by using the help of the Matlab 2012 fuzzy toolbox software using the centroid method for defuzzification.
\end{abstract}

Keywords:: Rice, Fuzzy Inference System, FIS, MAPE , Matlab 2012

\section{PENDAHULUAN}

Indonesia adalah negara argraris tempat tumbuh jenis tanaman pangan.Dahulu indonesia pernah dikenal sebagai negara swasembada pangan.Tanaman pangan segala jenis tanaman yang daat menghasilkan karbohidrat dan protein. Tanaman pangan dapat dibedakan menjadi beberapa kriteria diantaranya adalah Serelia (padi, gandum,sorghum) dan Biji-bijian (kacang tanah, kacang merah, kacang hijau.-) serta Umbi-umbian (ubi jalar, singkong, talas, kentang).

Padi (Oryza sativa) adalah sumber makanan pokok bagi masyarakat Indonesia. Sebagian besar beras yang dikonsumsi adalah merupakan hasil produktifitas padi nasional. Seringkali pemerintah kesulitan dalam memperkirakan kecukupan bahan pangan pokok yang dapat disediakan oleh pertanian dalam negeri. Karena itu diperlukan suatu metode untuk memprediksi hasil panen padi secara akurat dan tepat.

Sektor pertanian di Nusa Tenggara Timur bukan merupakan unggulan dari kegiatan perekonomian masyarakat. Hal ini disebabkan kondisi geografis NTT yang kurang mendukung untuk kegiatan usaha di sektor pertanian. Meskipun demikian, prediksi hasil pertanian, khususnya hasil panen padi diperlukan untuk diprediksi agar dapat didapat suatu peramalan dalam menentukan hasil produksi padi pada tahun 2017.

Metode fuzzy logic dalam hal ini Fuzzy Inference System (FIS) banyak sekali diaplikasikan untuk peramalan atau prediksi. Fuzzy logic memiliki kelabihan dalam meramalkan hasil panen untuk tahun berikut berdasarkan hasil panen pada tahun sebelumnya dan informasi diambil dari fuzzy information yang diberikan. Dari fuzzyinformation dapat dibuat rule atau aturan sebagai pertimbangan dalam memprediksi hasil panen.

Dengan demikian petani bisa memperkirakan hasil panen padi pada tahun berikut dan juga berapa keuntungan yang akan didapat.

\subsection{Perumusan Masalah}

Berdasarkan uraian yang telah dikemukakan, maka yang dibahas dalam tugas ini adalah :

a. Bagaimana menyusun Fuzzy Inference System yang dapat digunakan untuk memprediksi hasil panen padi berdasarkan data luas baku sawah, luas tanam, luas panen, dan produksi padi

b. Bagaiamana memvalidasi output Fuzzy Inference System yang telah disusun sehingga dapat menjamin kemampuan dari metode tersebut dalam memprediksi hasil panen padi NTT tahun 2017 


\subsection{Tujuan}

Tujuan yang hendak dicapai dalam penelitian ini adalah :

a. Membuat prediksi yang mampu meramalkan hasil panen padi di NTT

b. Menguji tingkat validitas dan akurasi outputFuzzyInference System yang telah disusun sehingga dapat menjamin kemampuan dari metode tersebut dalam memprediksi hasil panen padi di NTT pada tahun 2017.

\subsection{Ruang Lingkup}

Adapun ruang lingkup penelitian antara lain adalah sebagai berikut :

a. Membuat prediksi hasil panen padi di NTT pada tahun 2017 dengan metode Fuzzy Inference System

b. Menentukan tingkat akurasi dan validitas prediksi hasil panen padi di NTT berdasarkan metode Fuzzy Inference System

\section{TINJAUAN PUSTAKA}

\subsection{Logika Fuzzy}

Logika Fuzzy adalah peningkatan dari logika Boolean yang berhadapan dengan konsep kebenaran sebagian. Di mana logika klasik menyatakan bahwa segala hal dapat diekspresikan dalam istilah binary ( 0 atau 1, hitam atau putih, ya atau tidak), logika fuzzy menggantikan kebenaran Boolean dengan tingkat kebenaran.

Logika fuzzy memungkinkan nilai keanggotan antara 0 dan 1, tingkat keabuan dan juga hitam dan putih dan dalam bentuk linguistik, konsep tidak pasti seperti "sedikit", "lumayan" dan "sangat". Logika fuzzy berhubungan dengan set fuzzy dan teori kemungkinan. Logika fuzzy diperkenalkan oleh Dr. Lofti Zadeh dari Universitas California, Berkeley pada 1965. Pada prinsipnya himpunan fuzzy atau fuzzy set adalah perluasan himpunan crips yaitu himpunan yang membagi sekelompok individu ke dalam dua kategori yaitu anggota dan bukan anggota.

Pada himpunan tegas (crips), nilai keanggotaan suatu item $\mathrm{x}$ dalam suatu himpunan $\mathrm{A}$, yang sering ditulis $\mu \mathrm{A}[\mathrm{x}]$, memiliki dua kemungkinan yaitu :

a. Satu (1) yang berarti bahwa suatu item menjadi anggota dalam suatu himpunan

b. Nol (0) yang berarti bahwa suatu item tidak menjadi anggota dalam suatu himpunan.

Pada himpunan crips, nilai keanggotaan ada dua kemungkinan, yaitu 0 dan 1. Sedangkan pada himpunan fuzzy nilai keanggotaan terletak pada rentang 0 dan 1 .

Semesta pembicaraan adalah keseluruhan nilai yang diperbolehkan untuk dioperasikan dalam suatu variabel fuzzy. Semesta pembicaraan merupakan himpunan bilangan real yang senantiasa naik (bertambah) secara monoton dari kiri ke kanan.
Nilai semester pembicaraan dapat berupa bilangan positif maupun negatif.

Domain himpunan fuzzy adalah keseluruhan nilai yang diijinkan dalam semesta pembicaraan dan boleh dioperasikan dalam suatu himpunan fuzzy. Fungsi keanggotaan (membership function) adalah suatu kurva yang menunjukkan pemetaan titik-titik input data kedalam nilai keanggotaan yang memiliki interval antara 0 sampai 1 . Salah satu cara yang dapat digunakan untuk mendapatkan nilai keanggotaan adalah dengan melalui pendekatan fungsi. Ada beberapa fungsi yang bisa digunakan, diantaranya adalah :

1. Representasi linear

2. Representasi segitiga

3. Representasi trapesium

4. Representasi kurva bentuk bahu

5. Representasi kurva S (sigmoid)

6. Representasi bentuk lonceng

\subsection{Fuzzy Inference System Model Mamdani}

Metode Mamdani sering dikenal dengan nama metode min-max. metode ini diperkenalkan oleh Ebrahim Mamdani pada tahun 1975. Untuk mendapatkan output diperlukan 4 tahapan, diantaranya adalah :

1. Pembentukan himpunan fuzzy

Pada metode Mamdani baik variabel input aupun variabel output dibagi menjadi satu atau lebih himpunan fuzzy

2. Aplikasi fungsi implikasi

Pada metode Mamdani, fungsi implikasi yang digunakan adalah $\mathrm{min}$.

3. Komposisi aturan

Metode yang digunakan adalah melakukan inferensi sistem fuzzy, yaitu metode max (maximum). Secara umum dapat dituliskan : $\mu \mathrm{sf}[\mathrm{Xi}]=\max (\mu \mathrm{sf}[\mathrm{Xi}], \mu \mathrm{kf}[\mathrm{Xi}])$

Dengan :

$\mu \mathrm{sf}[\mathrm{Xi}]=$ nilai keanggotaan solusi fuzzy sampai aturan ke $\mathrm{i}$

$\mu \mathrm{kf}[\mathrm{Xi}]=$ nilai keanggotaan konsekuen fuzzy aturan ke i

4. Penegasan (defuzzifikasi)

Dufuzzifikasi pada komposisi aturan Mamdani menggunakan metode centroid. Dimana metode ini, solusi crips diperbolehkan dengan cara mengambil titik pusat daerah fuzzy.

Metode centroiddirumuskan sebagai berikut :

$$
\begin{array}{r}
\mu(x)=\frac{\int_{a}^{b} x \mu(x) d x}{\int_{a}^{b} \mu(x) d x} \\
\text { Atau } \mu(x)=i=\frac{\sum_{i=1}^{n} x_{i} \mu\left(x_{i}\right)}{\sum_{i=1}^{n} \mu\left(x_{i}\right)}
\end{array}
$$

Ada dua keuntungan menggunakan metode centroid, yaitu :

1. Nilai defuzzifikasi akan bergerak secara halus sehingga perubahan dari suatu 
himpunan fuzzy juga akan berjalan dengan halus

2. Lebih mudah dalam perhitungan.

\section{METODE PENELITIAN}

\subsubsection{Bahan}

Adapun bahan atau data yang digunakan dalam tugas ini adalah data pertanian dari Badan Pusat Statistik Propinsi Nusa Tenggara Timur tahun 2011. Data diurutkan berdasarkan kecamatan yang berada pada Kabupaten Kota di NTT. Ada dua tabel yang digunakan yaitu tabel luas tanam, luas panen, dan produksi padi per Kabupten Kota NTT dan tabel luas baku sawah per Kabuptaen Kota di NTT.

Tabel 1. Luas Baku Sawah per Kabupaten Kota NTT Tahun 2017

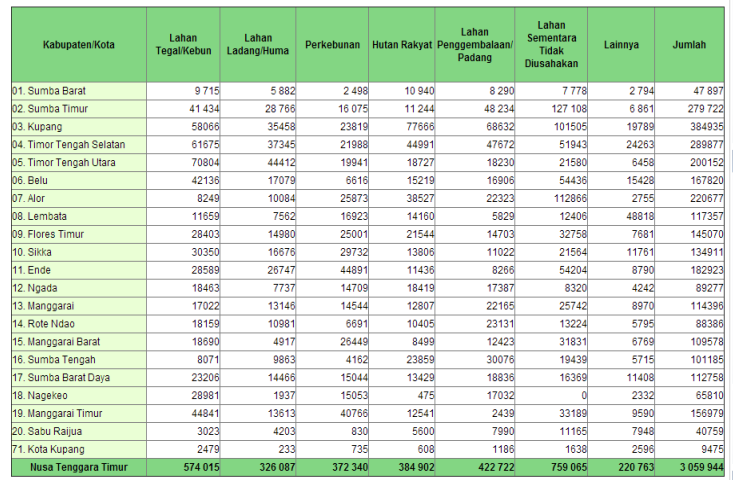

Catatan: Diolah dari Luas Baku Lahan NTT

Sumber : Badan Pusat Statistik Propinsi Nusa Tenggara Timur

Tabel 2. Luas Tanam, Luas Panen, dan Produksi Padi per Kabupaten Kota Nusa Tenggara Timur Tahun 2017

\begin{tabular}{|c|c|c|c|c|c|}
\hline \multirow[b]{2}{*}{ Kabupaten/Kota } & \multirow{2}{*}{ Luas Tanam (Ha) } & \multirow{2}{*}{ Luas Panen (Ha) } & \multirow{2}{*}{$\begin{array}{l}\text { Rata-Ratat asasil } \\
\text { [Wwita) }\end{array}$} & \multicolumn{2}{|c|}{ Produks (Ton) } \\
\hline & & & & Gaban kering glung & Beras \\
\hline 01. Sumba Barat & 6542 & 5925 & 36,3 & 21505 & 12015 \\
\hline 02. Surnba Timur & 17643 & 14888 & 35,49 & 52839 & 29513 \\
\hline 03. Kupang & 15999 & 14670 & 34,01 & 49896 & 27852 \\
\hline 04. Timor Tengah Selatan & 4 4176 & 3537 & 37,04 & 13101 & 7322 \\
\hline 05. Timor Tengah Utara & 4700 & 0632 & 33,1 & 31879 & 17788 \\
\hline o6. Belu & 7844 & 7962 & 37,13 & 29562 & 16522 \\
\hline 07. Alor & 2186 & 4620 & 26.8 & 12382 & 6884 \\
\hline loc. Lembata & 7257 & 3836 & 25,07 & 9616 & 5341 \\
\hline 09. Flores Timur & 8150 & 8151 & 29,4 & 23965 & 13347 \\
\hline 10. Sikka & 11819 & 11359 & 27.83 & 31611 & 17588 \\
\hline 11. Ende & 5338 & 7041 & $33,47$. & 23568 & 13153 \\
\hline 12. Ngada & 44433 & $6286]$ & 38,4 & 24136 & 13496 \\
\hline 13. hangagrai & 15127 & 18125 & 37.5 & 67971 & 37994 \\
\hline 14. Rote Ndao & 14578 & 14130 & 39,92 & 56414 & 31560 \\
\hline 15. Hanggarai Barat & 13149 & 17170 & 37,01 & 63549 & 35510 \\
\hline 16. Sumba Tengah & 20055 & 18004 & 30,79 & 55436 & 30897 \\
\hline 17. Sumba BaraI Daya & 5659 & 5374 & 37,54 & 23931 & 13377 \\
\hline 18. Nagekeo & 8490 & 8076 & 37,13 & 29984 & 16758 \\
\hline 19. hanggrai Timur & 19972 & 18984 & 38,09 & 72320 & 40434 \\
\hline 20. Sabu Rajua & 1051 & 1065 & 37,02 & 3943 & 2204 \\
\hline 71. Kota Kupano & 203 & 259 & 36.91 & 956 & 534 \\
\hline Nusa Tenggara Timur & 193441 & 200094 & 34,91 & 698566 & 390095 \\
\hline
\end{tabular}

Sumber : Badan Pusat Statistik Propinsi Nusa Tenggara Timur

\subsubsection{Alat}

Adapun alat yang digunakan dalam laporan tugas ini dibagi dalam perangkat keras dan perangkat lunak, adalah sebagai berikut :

a. Perangkat keras

- Processor : Intel ${ }^{\circledR}$ Core ${ }^{\text {TM }}$ i3-3217U CPU@1.80Ghz 1.70GHz

- Memory : DDR 2 RAM 1.70 GB
- Harddisk : 320 GB

b. Perangkat lunak

- Sistem operasi : Windows 7 Home Premium 64-bit operating system

- Software Matlab : MatLab Version 2012 .R2012a

\subsection{Metode Kerja}

Adapun metode kerja yang dilakukan adalah sebagai berikut :

1. Pengumpulan data

Meliputi data luas baku sawah, luas tanam, luas panen, dan produksi dari kota Banda Aceh yang diambil per Kabupaten Kota pada tahun 2017

2. Identifikasi data

Identifikasi data dilakukan untuk menentukan variabel dan semesta pembicaraan yang diperlukan dalam melakukan perhitungan dan analisis masalah.

3. Pengolahan data

Pengolahan data dilakukan dengan menggunakan bantuan software Matlab 2012 dengan menggunakan fasilitas yang disediakan pada toolboxfuzzy dan melakukan langkah-langkah berikut :

a. Pembentukkan himpunan fuzzy (fuzzy set)

b. Pembentukkan aturan-aturan

c. Penentuan komposisi (aggregate) aturan

d. Penegasan (defuzzyfication)

4. Penarikan kesimpulan

Jika digambarkan dengan diagram alir adalah sebagai berikut :

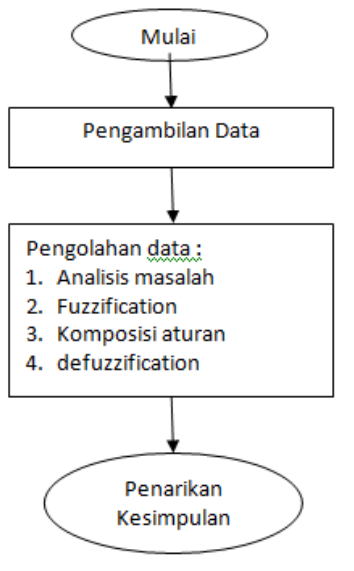

Gambar 1. Diagram Alir

\section{HASIL DAN PEMBAHASAN}

\subsection{Analisis Masalah}

Untuk masalah prediksi hasil panen padi Kabupaten dan Kota di NTT pada tahun 2012,maka ada beberapa variabel yang terlibat di dalamnya yaitu variabel input dan variabel output. Variabel input antara lain adalah luas baku sawah, luas tanam dan luas panen. Sedangkan untuk variabel output adalah produksi padi. Untuk lebih jelasnya dapat dilihat pada tabel 3 yang berisi tentang 
variabel input dan variabel output beserta semesta pembicaraan tiap variabel tersebut.

Tabel 3. Penentuan Varibel dan Semesta Pembicaraan

\begin{tabular}{|c|l|c|l|}
\hline Fungsi & \multicolumn{1}{|c|}{ Nama Variabel } & $\begin{array}{c}\text { Semesta } \\
\text { Pembicaraan }\end{array}$ & \multicolumn{1}{|c|}{ Keterangan } \\
\hline Input & Luas Baku Sawah & {$[0-197]$} & Jumlah Luas Baku Sawa (Ha) \\
& Luas Tanam & {$[0-51]$} & Jumlah Luas baku Tanam (Ha) \\
& Luas Panen & {$[0-51]$} & Jumlah Luas Panen (Ha) \\
\hline Output & Produksi & {$[0-220]$} & Jumlah Hasil Panen Padi (ton) \\
\hline
\end{tabular}

\subsection{Fuzzification}

Setelah menentukan variabel dan semesta pembicaraan, maka akan dilakukan penghimpunan dari semesta pembicaraan. Jadi dapat diketahui domain atau rentang angka yang diperbolehkan dari tiap-tiap variabel input maupun variabel output.

Tabel 4 Himpunan Fuzzy

\begin{tabular}{|c|c|c|c|c|}
\hline Fungsi & Nama Variabel & Himpunan & $\begin{array}{c}\text { Semesta } \\
\text { Pembicaraan }\end{array}$ & Domain \\
\hline \multirow{3}{*}{ Input } & Luas Baku Sawah & \begin{tabular}{|l|} 
Kecil \\
Sedang \\
Luas
\end{tabular} & {$[0-197]$} & $\begin{array}{l}{[0-130]} \\
{[100-185]} \\
{[130-197]}\end{array}$ \\
\hline & Luas Tanam & \begin{tabular}{|l} 
Kecil \\
Sedang \\
Luas
\end{tabular} & {$[0-51]$} & $\begin{array}{l}{[0-40]} \\
{[30-45]} \\
{[40-51]}\end{array}$ \\
\hline & Luas Panen & \begin{tabular}{|l} 
Kecil \\
Sedang \\
Luas
\end{tabular} & {$[0-51]$} & $\begin{array}{l}{[0-40]} \\
{[30-45]} \\
{[40-51]}\end{array}$ \\
\hline Output & Produksi & \begin{tabular}{|l|} 
Kecil \\
Sedang \\
Luas
\end{tabular} & {$[0-220]$} & $\begin{array}{l}{[0-150]} \\
{[100-190]} \\
{[150-220]}\end{array}$ \\
\hline
\end{tabular}

Berdasarkan himpunan fuzzy yang telah dibentuk, maka dapat dibentuk kurva untuk menampilkan tiap variabel input dan output menggunakan fuzzytoolbox pada Matlab yaitu sebagai berikut :

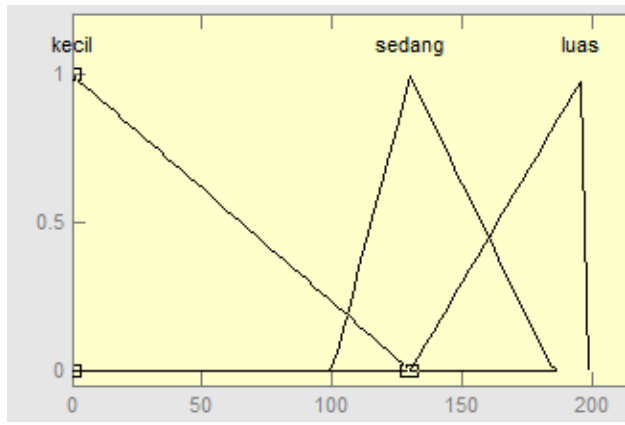

Gambar 2. Variabel Input Luas Baku Sawah

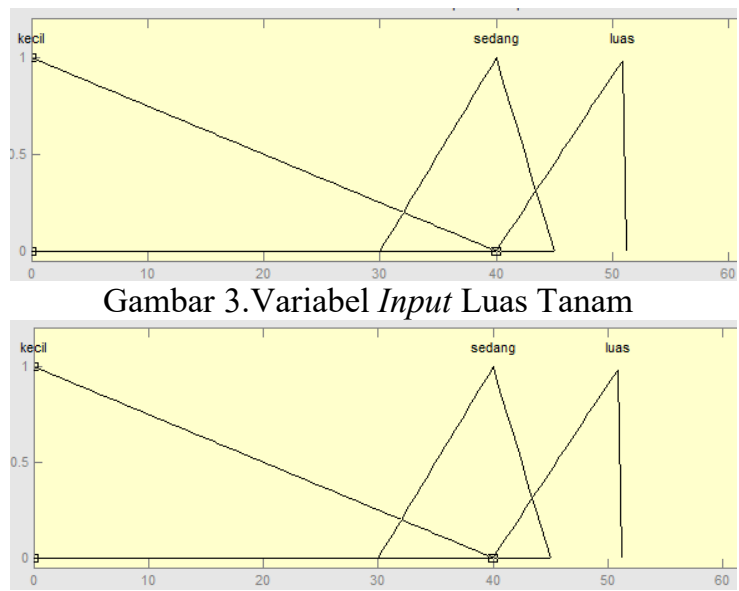

Gambar 4. Variabel Input Luas Panen

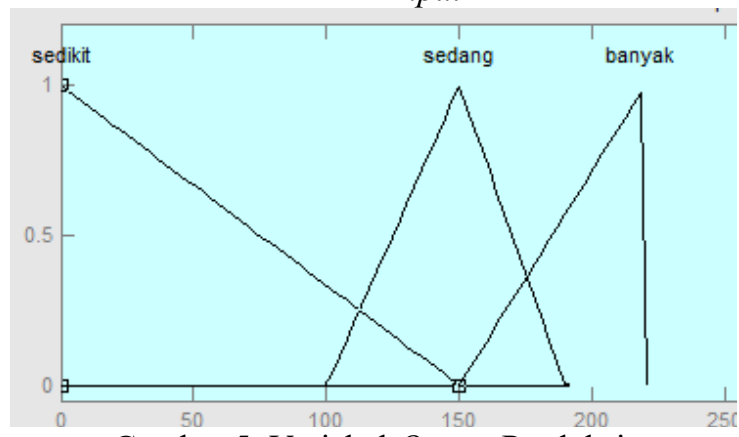

Gambar 5. Variabel Output Produksi

Untuk membuat fungsi keanggotaan (membership function), maka direpresentasikan variabel luas baku sawah, luas tanam, luas panen dan produksi padi adalah dalam bentuk kurva segitiga (trimf). Hal ini disebabkan karena hubungan antara data luas baku sawah, luas tanam, luas panen dan jumlah produksi bersifat linier dan dipengaruhi oleh waktu.

\subsection{Komposisi Aturan}

Setelah ditentukan fungsi keanggotaan variabel, maka dilakukan pembentukan aturan logika fuzzy. Berdasarkan data-data yang ada, dapat dibentuk aturan-aturan sebagai berikut :

1. If (luas baku sawah is kecil) and (luas tanam is kecil) and (luas panen is kecil) then (produksi is sedikit)

2. If (luas baku sawah is kecil) and (luas tanam is kecil) and (luas panen is sedang) then (produksi is sedikit)

3. If (luas baku sawah is kecil) and (luas tanam is kecil) and (luas panen is sedang) then (produksi is sedang)

4. If (luas baku sawah is kecil) and (luas tanam is sedang) and (luas panen is kecil) then (produksi is sedikit)

5. If (luas baku sawah is kecil) and (luas tanam is sedang) and (luas panen is sedang) then (produksi is sedikit)

6. If (luas baku sawah is kecil) and (luas tanam is sedang) and (luas panen is sedang) then (produksi is sedang)

7. If (luas baku sawah is kecil) and (luas tanam is sedang) and (luas panen is sedang) then (produksi is banyak)

8. If (luas baku sawah is kecil) then (luas tanam is luas) and (luas panen is kecil) then (produksi is sedikit)

9. If (luas baku sawah is kecil) then (luas tanam is luas) and (luas panen is kecil) then (produksi is sedang)

10. If (luas baku sawah is kecil) then (luas tanam is luas) and (luas panen is sedang) then (produksi is sedikit)

11. If (luas baku sawah is kecil) then (luas tanam is luas) and (luas panen is sedang) then (produksi is sedang)

12. If (luas baku sawah is kecil) then (luas tanam is luas) and (luas panen is sedang) then (produksi is banyak) 
13. If (luas baku sawah is kecil) then (luas tanam is luas) and (luas panen is luas) then (produksi is sedikit)

14. If (luas baku sawah is kecil) then (luas tanam is luas) and (luas panen is luas) then (produksi is sedang)

15. If (luas baku sawah is kecil) then (luas tanam is luas) and (luas panen is luas) then (produksi is banyak)

16. If (luas baku sawah is sedang) and (luas tanam is kecil) and (luas panen is kecil) then (produksi is sedikit)

17. If (luas baku sawah is sedang) and (luas tanam is kecil) and (luas panen is sedang) then (produksi is sedikit)

18. If (luas baku sawah is sedang) and (luas tanam is kecil) and (luas panen is sedang) then (produksi is sedang)

19. If (luas baku sawah is sedang) and (luas tanam is sedang) and (luas panen is kecil) then (produksi is sedikit)

20. If (luas baku sawah is sedang) and (luas tanam is sedang) and (luas panen is sedang) then (produksi is sedikit)

21. If (luas baku sawah is sedang) and (luas tanam is sedang) and (luas panen is sedang) then (produksi is sedang)

22. If (luas baku sawah is sedang) and (luas tanam is sedang) and (luas panen is sedang) then (produksi is banyak)

23. If (luas baku sawah is sedang) then (luas tanam is luas) and (luas panen is kecil) then (produksi is sedikit)

24. If (luas baku sawah is sedang) then (luas tanam is luas) and (luas panen is kecil) then (produksi is sedang)

25. If (luas baku sawah is sedang) then (luas tanam is luas) and (luas panen is sedang) then (produksi is sedikit)

26. If (luas baku sawah is sedang) then (luas tanam is luas) and (luas panen is sedang) then (produksi is sedang)

27. If (luas baku sawah is sedang) then (luas tanam is luas) and (luas panen is sedang) then (produksi is banyak)

28. If (luas baku sawah is sedang) then (luas tanam is luas) and (luas panen is luas) then (produksi is sedikit)

29. If (luas baku sawah is sedang) then (luas tanam is luas) and (luas panen is luas) then (produksi is sedang)

30. If (luas baku sawah is sedang) then (luas tanam is luas) and (luas panen is luas) then (produksi is banyak)

31. If (luas baku sawah is luas) and (luas tanam is kecil) and (luas panen is kecil) then (produksi is sedikit)

32. If (luas baku sawah is luas) and (luas tanam is kecil) and (luas panen is sedang) then (produksi is sedikit)
33. If (luas baku sawah is luas) and (luas tanam is kecil) and (luas panen is sedang) then (produksi is sedang)

34. If (luas baku sawah is luas) and (luas tanam is sedang) and (luas panen is kecil) then (produksi is sedikit)

35. If (luas baku sawah is luas) and (luas tanam is sedang) and (luas panen is sedang) then (produksi is sedikit)

36. If (luas baku sawah is luas) and (luas tanam is sedang) and (luas panen is sedang) then (produksi is sedang)

37. If (luas baku sawah is luas) and (luas tanam is sedang) and (luas panen is sedang) then (produksi is banyak)

38. If (luas baku sawah is luas) then (luas tanam is luas) and (luas panen is kecil) then (produksi is sedikit)

39. If (luas baku sawah is luas) then (luas tanam is luas) and (luas panen is kecil) then (produksi is sedang)

40. If (luas baku sawah is luas) then (luas tanam is luas) and (luas panen is sedang) then (produksi is sedikit)

41. If (luas baku sawah is luas) then (luas tanam is luas) and (luas panen is sedang) then (produksi is sedang)

42. If (luas baku sawah is luas) then (luas tanam is luas) and (luas panen is sedang) then (produksi is banyak)

43. If (luas baku sawah is luas) then (luas tanam is luas) and (luas panen is luas) then (produksi is sedikit)

44. If (luas baku sawah is luas) then (luas tanam is luas) and (luas panen is luas) then (produksi is sedang)

45. If (luas baku sawah is luas) then (luas tanam is luas) and (luas panen is luas) then (produksi is banyak)

\section{Penegasan (Defuzzification)}

Langkah terakhir adalah penegasan, yaitu cara untuk mengekstraksi nilai crips dari himpunan fuzzy sebagai nilai representatif. Metode defuzzifikasi dalam tugas ini menggunakan metode centroid dan penegasan dilakukan dengan bantuan Matlab 7 fuzzytoolbox.

Dari hasil pengujian dengan metode centroid dengan input jumlah luas baku sawah $508.50 \mathrm{Ha}$, luas tanam $75 \mathrm{Ha}$, luas panen $75 \mathrm{Ha}$ akan menghasilkan jumlah produksi padi sebesar 255 ton. Penalaran fuzzy dengan metode centroid digambarkan seperti pada gambar 6 . 


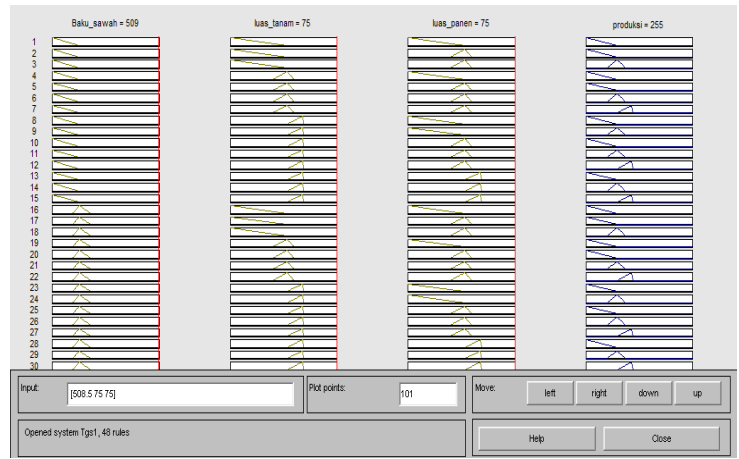

Gambar 6. Penalaran Fuzzy dengan Metode Centroid

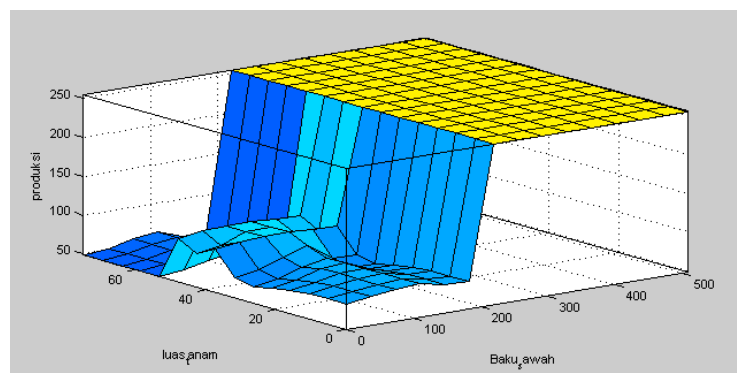

Gambar 7. Surface Penalaran Fuzzy Prediksi

Produksi Padi

Dari aturan atau kaidah yang diberikan maka dapat dilakukan pengujian antara data riil dengan hasil peramalan atau prediksi jumlah prouksi padi dengan variabel input adalah luas baku sawah, luas tanam dan luas panen.

Tabel 5. Perbandingan Jumlah Produksi Padi Riil dengan Prediksi Jumlah Produksi Padi Kabupaten Kota NTT dengan Model FuzzyMamdani

\begin{tabular}{|c|c|c|c|c|c|c|}
\hline No & Kecamatan & $\begin{array}{c}\text { Luas Baku } \\
\text { Sawah }(\mathrm{Ha})\end{array}$ & $\begin{array}{l}\text { Luas Tanam } \\
\text { (Ha) }\end{array}$ & $\begin{array}{l}\text { Luas Panen } \\
(\mathrm{Ha})\end{array}$ & $\begin{array}{l}\text { Produksi } \\
\text { Riil (Ton) }\end{array}$ & $\begin{array}{r}\text { Prediks } \\
\text { Produk } \\
\text { (Ton) }\end{array}$ \\
\hline 1 & Sumba Barat & 62.50 & 0 & 0 & 0 & 0 \\
\hline 2 & Sumba Timur & 45.21 & 13 & 6 & & \\
\hline 3 & Kupang & 63.50 & 0 & 0 & 0 & 0 \\
\hline 4 & Timor Tengah Selatan & & & & & \\
\hline 5 & Timor Tengah Utara & 197.00 & 16 & 16 & 66 & 54.4 \\
\hline 6 & Belu & & & & & \\
\hline 7 & Alor & 23.00 & 0 & 0 & 0 & 0 \\
\hline 8 & Lembata & & & & & \\
\hline 9 & Flores Timur & 23.50 & 7 & 7 & 28 & 49.9 \\
\hline 10 & Sikka & & & & & \\
\hline 11 & Ende & 4.00 & 0 & 0 & 0 & 0 \\
\hline 12 & Ngada & 0.00 & 0 & 0 & 0 & 0 \\
\hline 13 & Manggarai & & & & & \\
\hline 14 & Rote Ndao & & & & & \\
\hline 15 & Sumba Tengah & & & & & \\
\hline 16 & Manggarai Barat Daya & & & & & \\
\hline 17 & Nagekeo & & & & & \\
\hline 18 & Manggarai Timur & & & & & \\
\hline 19 & Sabu Raijua & & & & & \\
\hline \multirow[t]{3}{*}{20} & Kota Kupang & 30.00 & 1 & 1 & 4 & 40.7 \\
\hline & & 105.00 & 51 & 51 & 220 & 110 \\
\hline & TOTAL & 508.50 & 75 & 75 & 318 & 255 \\
\hline
\end{tabular}

Sumber : Badan Pusat Statistik Propinsi Nusa Tenggara Timur

\subsection{Pengujian Data}

Berdasarkan data yang telah diuji maka dapat dihitung nilai akurasi dari prediksi yang dilakukan dari validasi data dengan model
fuzzyMamdani dan metode deffuzifikasi yang digunakan adalah centroid. Dengan menggunakan formula Mean Absolute Percentage Error (MAPE) atau Rata-rata Persentase Kesalahan Absolut, dari model fuzzyMamdani dengan $X t$ adalah data riil dan $F t$ adalah ramalan, $n$ adalah banyaknya data maka MAPE dari pengujian data sebagai berikut :

$$
\begin{aligned}
& \text { Error }(\mathrm{E}) \text { total }=\mathrm{Xt}-\mathrm{Ft} \\
& =318-255 \\
& =63 \\
& P E=\left[\frac{X_{t-} F_{t}}{X_{t}}\right] \times 100=\frac{318-255}{318} \times 100 \\
& =19.81
\end{aligned}
$$

PE :Percentage Error

$$
M A P E=\frac{\sum|P E|}{n}=\frac{19.81}{9}=2.2 \%
$$

Kebenaran $=100 \%-$ MAPE $=100 \%-2.2 \%=$ $97.8 \%$

Dari hasil perhitungan maka didapatkan kesimpulan model Fuzzy yang diterapkan untuk memprediksi hasil panen padi kotadi NTT adalah memiliki rata-rata persentase kesalahan absolut adalah sebesar 2.2\% dengan tingkat akurasi $97.8 \%$. Maka dapat disimpulkan bahwa hasil perhitungan model fuzzy pada prediksi ini sudah mendekati kebenaran.

\section{KESIMPULAN}

Fuzzy Inference System (FIS) dengan model Mamdani yang telah dibangun dapat digunakan untuk memperkiraan jumlah produksi padi di Kabupaten Kota di NTT dengan nilai kebenaran mencapai 97.8\%. Untuk menentukan jumlah produksi padi tahun 2017 maka dilakukan pengolahan data dengan menggunakan bantuan software Matlab 2012 toolbox fuzzy dengan menggunakan metode centroid untuk defuzzifikasi. Dengan memasukkan variabel input yang sesuai dengan keadaan geografi kabupaten kota di proponsi NTT maka luas baku sawah sebesar 508.50 Ha, luas tanam sebesar $75 \mathrm{Ha}$, luas panen sebesar $75 \mathrm{Ha}$, didapat untuk jumlah produksi pani pada tahun 2017 adalah sebesar 255 ton beras.

\section{DAFTAR PUSTAKA}

[1] Abdurrahman, Ginanjar. 2011. Penerapan metode Tsukamoto (Logika Fuzzy)

Dalam Sistem Pendukung Keputusan Untuk Menentukan Jumlah

Produksi Barang Berdasarkan Data Persediaan dan Jumlah

Permintaan. Jurnal Universitas Negeri Yogyakarta.

[2] Ginting, Rosnani. 2007. Sistem Produksi. Yogyakarta: Graha Ilmu 2018.

[3] Engelbrecht, A.P (2007). Computational Intelligence an Introduction. John 
Willey\&Sons Ltd. England

[4] Jang, J.S.R, Tsai-Sun.C, Mizutani, E. (1997). Neuro Fuzzy and Soft Computing. Prentice Hall International, New Jersey

[5] Haryati, N.E. Perencanaan Jumlah Produk Menggunakan Fuzzy Mamdani Berdasarkan Prediksi Permintaan.

[6] Ika, K. 2007. Sistem Pendukung Keputusan Penanganan Kesehatan Balita Menggunakan Fuzzy Mamdani.

[7] Kartina, D. 2010. Penerapan Inferensi Fuzzy Untuk Kendali Suhu Ruangan Pada Pendingin Ruangan (AC).

[8] Kusumadewi, S. 2002. Analisis Desain Sistem Fuzzy Menggunakan Tool Box Matlab. Yogyakarta : Graha Ilmu.

[9] Kusumadewi, S. dan Purnomo. 2006. Aplikasi Logika Fuzzy Untuk Mendukung Keputusan. Yogyakarta : Graha Ilmu.

[10] Makridakis. 1999. Metode Aplikasi Peramalan Edisi Kedua Jilid Satu. Jakarta Barat : Binarupa Aksara.

[11] Octavia, M. Perencanaan Jumlah Produksi Meja Aluminium Untuk Meminimalkan Biaya Produksi Dengan Menggunakan Fuzzy Mamdani.

[12] Pal. K. Sankar. 1989. Fuzzy Pendekatan Matematik Untuk Pengenalan Pola. Jakarta : Universitas Indonesia.

[13] Setiadji. 2009. Himpunan dan Logika Samar serta Aplikasinya. Yogyakarta : Graha Ilmu.

[14] Susilo, Frans. SJ. 2006. Himpunan dan Logika Kabur serta Aplikasinya. Yogyakarta : Graha Ilmu.

[15] Sutikno. Perbandingan Metode Defuzzifikasi Aturan Mamdani Pada Sistem

Kendali Logika Fuzzy (Studi Kasus Pada Pengaturan Kecepatan Motor DC).

[16] Yulyantari, 2011. Computer Aided Instruction Artificial Intelligence. $<$ www.yulyantari.com/tutorial/media.php $>$. diakses tanggal 25 April 2019. 